\title{
CORRIGENDUM
}

\section{GATA3 interacts with and stabilizes HIF-1 $\alpha$ to enhance cancer cell invasiveness}

M-C Lin, J-J Lin, C-L Hsu, H-F Juan, P-J Lou and M-C Huang

Oncogene (2017) 36, 4380; doi:10.1038/onc.2017.196; published online 12 June 2017

Correction to: Oncogene (2017) 36, 4243-4252; doi: 10.1038/ onc.2017.8; published online 6 March 2017

The authors noted an error in the bottom panel of Figure $2 c$. A revised version is shown below and the text of the manuscript remains unchanged.

The authors would like to apologize for any inconvenience caused and confirm that the conclusions drawn from this research are not affected by this error. (c) (i) This work is licensed under a Creative Commons Attribution 4.0 International License. The images or other third party material in this article are included in the article's Creative Commons license, unless indicated otherwise in the credit line; if the material is not included under the Creative Commons license, users will need to obtain permission from the license holder to reproduce the material. To view a copy of this license, visit http://creativecommons.org/licenses/ by/4.0/

() The Author(s) 2017
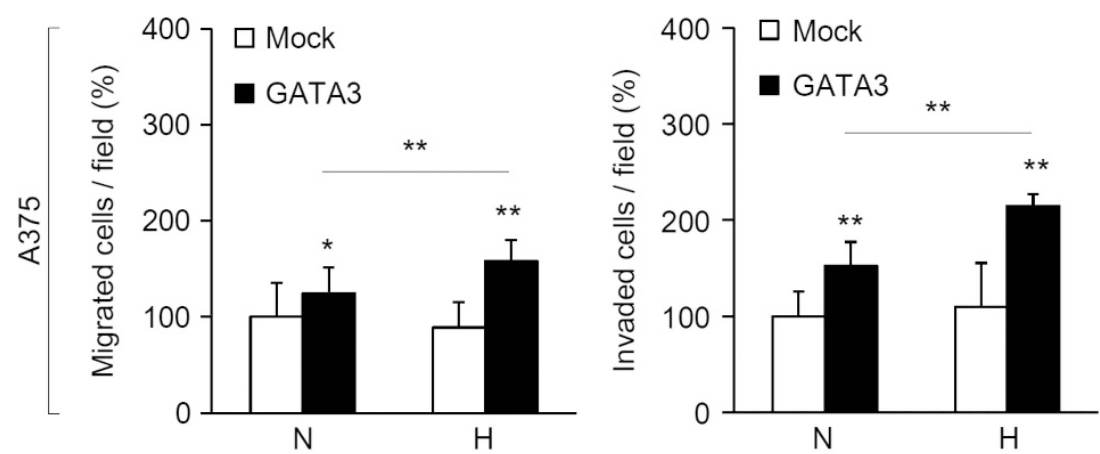

Figure 2. 